\title{
Efficacy of Ethephon on Vegetative Annuals
}

\author{
Terri W. Starman, ${ }^{1}$ \\ Melissa C. Robinson, ${ }^{2}$ and \\ Kristen L. Eixmann ${ }^{3}$
}

Additional INDEX WORds. Florel, (2chloroethyl) phosphonic acid, height reduction, internode elongation

Summary. Plant response to ethephon treatment was tested on 27 cultivars of vegetative annuals that have spreading and trailing growth habits. A control treatment was compared to $\mathbf{5 0 0}$ and $1000 \mathrm{mg} \cdot \mathrm{L}^{-1}(\mathrm{ppm})$ foliar spray treatments of ethephon. Plant height and/or width index were significantly reduced for $81 \%$ of the cultivars tested. Responsive cultivars were alternanthera (Alternanthera dentata), brachyscome (Brachyscome iberidifolia) 'Toucan Tango'; calibrachoa (Calibrachoa hybrids) 'Colorburst Red', 'Million Bells Cherry Pink', and 'Trailing Pink'; diascia (Diascia xbybrida) 'Sunchimes Rose' and 'Red Ace'; double impatiens (Impatiens wallerana) 'Tioga Red' and 'Tioga White'; sweetpotato vine (Ipomoea batatas) 'Sweet Caroline Bronze'; lantana (Lantana camara) 'Patriot Cherry' and 'Samantha'; nemesia (Nemesia $\times$ bybrida) 'Aromatica Dark Lavender', 'Blue Bird', and 'Blueberry Sachet'; nolana (Nolana paradoxa) 'Blue Eyes'; ivy geranium (Pelargonium bybrida) 'King of Balcon'; petunia (Petunia $\times$ bybrida) 'Cascadia Pink', 'Mini Bright Pink', and 'Supertunia Mini Purple'; bacopa (Sutera cordata) 'Bridal Showers'; and vinca vine (Vinca minor) 'Illumination'. Ethephon was not effective on monopsis (Monopsis unidentata) 'Royal Flush',

Department of Horticultural Sciences, Mail Stop 2133, Texas A\&M University, College Station, TX 77843-2133.

This research was funded in part by the Texas Agricultural Experiment Station. The authors wish to thank Ball FloraPlant, Bodger Botanicals, D.S. Cole Growers, EuroAmerican and The Flower Fields for donation of plant materials. Mention of a trademark, proprietary product, or vendor does not constitute a guarantee or warranty of the product by the author, Texas A\&M University, or the Texas Agricultural Experiment Station, and does not imply its approval to the exclusion of other products or vendors that also may be suitable.

${ }^{1}$ Associate professor of floriculture.

${ }^{2}$ Graduate student.

${ }^{3}$ Research assistant. 
persicaria (Persicaria microcephala) 'Red Dragon', or calibrachoa 'Liricashower Rose'. Different cultivars of petunia showed varied responses to ethephon treatments as did trailing snapdragon (Antirrbinum majus) 'Chandelier Yellow' and 'Luminaire Yellow'. Flower number was reduced in $55 \%$ of the cultivars due to a delay in flowering. The experiment finds efficacy of ethephon for most cultivars treated at rates greater than or equal to that used commercially, however more research is needed to determine optimum concentrations for the specific cultivars. Chemical name used: ethephon [(2-chloroethyl) phosphonic acid].

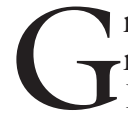
rowers produce vegetative annuals in 4 - and 5 -inch (10.2- to 12.7-cm) containers to market for bedding and container gardens and are challenged to keep those with trailing, spreading growth habits sufficiently compact so pruning is not needed before shipping. Several of the trailing, spreading vegetative annuals branch sparsely, produce long internodes, grow vigorously, and become overgrown before they are flowering and marketable. It is of great interest to growers to find plant growth regulator chemicals (PGRs) that stimulate lateral bud development and branching and reduce internode elongation to avoid high labor costs associated with manual pinching and pruning.

The effect of PGRs depends on the plant species on which it is applied and is correlated with the rate and number of treatments. In earlier experiments, we determined certain cultivars of vegetative annuals are not responsive to daminozide (B-Nine; Uniroyal Chemical, Middlebury, Conn.) at 5000 $\mathrm{mg} \cdot \mathrm{L}^{-1}$, paclobutrazol (Bonzi; Uniroyal Chemical) at $50 \mathrm{mg} \cdot \mathrm{L}^{-1}$, or a tank mix of chlormequat chloride (Cycocel; Olympic Horticultural Products, Mainland, Pa.) at $1250 \mathrm{mg} \cdot \mathrm{L}^{-1}$ and daminozide at $2500 \mathrm{mg} \cdot \mathrm{L}^{-1}$ (Starman et al., 2002) or manual pinching (Starman and Faust, 1996) and both may delay flowering.

The negligible response to paclobutrazol and uniconazole (Sumagic; Valent USA, Marysville, Ohio), two triazole-type plant growth regulators which must be absorbed by plant stems, may be due to the dense leaf canopy of these vigorous plants being difficult to penetrate. Uniconazole or paclobutrazol foliar sprays or paclobutrazol drenches were not effective in reducing plant height and width or promoting branching of bougainvillea (Bougainvillea glabra $\times$ B. peruviana 'Barbara Karst'), which has a vigorous growth habit and requires frequent pruning (Aldrich and Norcini, 1996).

Types of plant growth regulators most often used to promote branching of floral crops are cytokinins like benzyl adenine (BA), dikegulac, and ethephon. BA increased branching of english ivy (Hedera canariensis) and pothos (Rhaphidophora aurea), two climbing, spreading foliage crops (Sieminska-Michalak, 1989). Dikegulac at 780 $\mathrm{mg} \cdot \mathrm{L}^{-1}$ increased number of branches per node and total number of branches of 18 cultivars of impatiens (Impatiens wallerana) (Starman, 1991). At 1560 $\mathrm{mg} \cdot \mathrm{L}^{-1}$, branching was excessive, plants were stunted, and leaves and flowers were misshapen (Starman, 1991). Ethephon at 500 and $1000 \mathrm{mg} \cdot \mathrm{L}^{-1}$ reduced plant width but delayed flowering by 8 to $11 \mathrm{~d}$ for scaevola (Scaevola aemula) 'New Wonder' (Starman and Williams, 2000). Ethephon at 1500 and $2000 \mathrm{mg} \cdot \mathrm{L}^{-1}$ increased the number of shoots for 'Sonia' and 'Mercedes' rose (Rosa hybrida) budded on to dog rose (Rosa canina) (Grzesik and Rudnicki, 1989).

Ethephon releases ethylene to the plant thereby causing various physical effects such as height retardation, flowering, branching, and leaf drop. The effects of ethephon depend on the age, size, and type of plant (Nelson, 2003). Commercially, ethephon is applied to stock plants to shorten internodes and provide healthier cuttings in greater amounts. Once propagules have been potted and roots are established, ethephon is sprayed to increase branching. After cuttings have begun growth, plants can be sprayed to decrease internode elongation, increase branching, and improve plant quality (i.e., marketability) (Styer, 2002).

Most plants are treated with ethephon 1 to 2 weeks after potting and can be sprayed again in another 1 to 2 weeks. It is essential that leaves stay wet for 3 to $4 \mathrm{~h}$ after treatment. The effective $\mathrm{pH}$ of the water/ethephon solution in the spray tank is between 4.0 and 4.5 (Styer, 2002). Most floral crops are treated with an ethephon concentration between 250 and $500 \mathrm{mg} \cdot \mathrm{L}^{-1}$ (Styer, 2002). Ethephon is applied as a foliar spray and uniform application and run off ensure complete coverage. Plants under stress, then sprayed with ethephon, exhibit leaf yellowing or leaf drop and have delayed rooting and slower growth (Styer, 2002). This is termed stress exaggeration (Styer, 2003). Therefore, plant health should be optimum before treating with ethephon.

The objective of this research project was to ascertain the potential use of ethephon on vegetative annuals with spreading and trailing growth habits. These plants require a manual pinch, repeated pruning or plant growth regulator application to produce wellproportioned, easy-to-ship plants. To reach this goal, the most commonly used commercial concentration and a more astringent one for herbaceous floral crops were compared to a water control to determine the efficacy of ethephon.

\section{Materials and methods}

Rooted cuttings of vegetative annuals were planted upon receipt from mid-January to early February 2002. One rooted cutting was potted per 4-inch container using Pro Mix BX (Premier Brands, New Rochelle, N.Y.). Plants were irrigated by hand and fertilized with constant liquid feed at $15 \mathrm{~N}-5.4 \mathrm{P}-14.1 \mathrm{~K}$, with nitrogen at $200 \mathrm{mg} \cdot \mathrm{L}^{-1}$. Warm-season plants were grown at $23.9 / 18.3{ }^{\circ} \mathrm{C}\left(75 / 65^{\circ} \mathrm{F}\right)$ and cool-season plants were grown at $18.3 / 12.8^{\circ} \mathrm{C}\left(65 / 55^{\circ} \mathrm{F}\right)$ day/night set points in separate glass greenhouses. The warm-season cultivars were alternanthera; sweetpotato vine 'Sweet Caroline Bronze;' lantana 'Patriot Cherry' and 'Samantha;' monopsis 'Royal Flush;' nolana 'Blue Eyes;' ivy geranium 'King of Balcon;' persicaria 'Red Dragon;' and vinca vine 'Illumination'.

Cultivars grown with cooler temperatures were trailing snapdragon 'Chandelier Yellow' and 'Luminaire Yellow;' brachyscome 'Toucan Tango;' calibrachoa 'Colorburst Red', 'Liricashower Rose', 'Million Bells Cherry Pink', and 'Trailing Pink;' diascia 'Sunchimes Rose' and 'Red Ace;' impatiens 'Tioga Red' and 'Tioga White;' nemesia 'Aromatica Dark Lavender', 'Blue Bird', and 'Blueberry Sachet;' petunia 'Cascadia Pink', 'Mini Bright Pink', and 'Supertunia Mini Purple;' and bacopa 'Bridal Showers.'

Plants were sprayed when roots had reached pot edge $(\approx 2$ weeks after potting) with ethephon at either 0,500 , or $1000 \mathrm{mg} \cdot \mathrm{L}^{-1}$. Ethephon was mixed with distilled water and one drop of Capsil 
(The Scotts Co., Marysville, Ohio), a blend of polyether-polymethylsiloxane copolymer and nonionic surfactant, before applying to plants. Capsil was used because it is recommended as a spray adjuvant. Plants were harvested in mid April when they were considered marketable. Marketable stage was defined as when the majority of control plants had foliage covering the pot so that no media showed, branches beginning to drape over the pot edge, and flowering with flowers distributed evenly across the plant canopy. Measurements included plant height, width index, and flower number. Plant width index was computed by averaging two plant widths taken across the leaf canopy in perpendicular directions. Plant height was measured from the bottom of the pot to the top of the plant.

Flower number was determined differently for each cultivar because mode of flowering differed among genera. Individual flowers were counted on those species with single flowers and inflorescenses were counted on those with spikes, racemes, or umbels. Two cultivars that did not flower during the course of the experiment were ones in which flowers are not commercially significant. These were sweetpotato vine 'Sweet Caroline Bronze' and vinca vine 'Illumination'. Each vegetative annual cultivar had five to seven single-plant replications (depending on cultivar) per treatment. The experiment was a completely randomized design and data were analyzed by analysis of variance using SAS (SAS Institute, Inc., Cary, N.C.) and Duncan's mean separation.

\section{Results and discussion}

Ethephon did not affect either plant height or width index of three of the 27 cultivars including calibrachoa 'Liricashower Rose', monopsis 'Royal Flush', and persicaria 'Red Dragon' (Tables 1 and 2). The morphology of the control, 500 , and $1000 \mathrm{mg} \cdot \mathrm{L}^{-1}$ plants showed no observable differences and plants treated with the highest concentration remained vigorous. The reason flower number was reduced with increased ethephon concentration was because flowering was delayed in calibrachoa 'Liricashower Rose' and monopsis 'Royal Flush' did not flower (Table 3). Flower number of persicaria 'Red Dragon' was not affected (Table 3 ). Further studies involving higher concentrations or multiple applications of ethephon on these cultivars may be beneficial.

It is interesting to note that trailing snapdragon 'Chandelier Yellow' had increased height (Table 1) and trailing snapdragon 'Luminaire Yellow' had increased plant width (Table 2) and flower number (Table 3 ) with ethephon treatment. These results with the trailing snapdragon cultivars were unique and differed from other cultivars tested.

Results for the remaining 22 cultivars showed brachyscome 'Toucan Tango', calibrachoa 'Trailing Pink', ivy geranium 'King of Balcon', and petunia 'Supertunia Mini Purple' had no reduction in plant height when treated with ethephon compared to the controls (Table 1). Six cultivars only had reduced

Table 1. The effect of ethephon foliar spray treatment on plant height $(\mathrm{cm})$ of vegetative annuals.

\begin{tabular}{|c|c|c|c|c|c|}
\hline \multirow[b]{3}{*}{ Common name } & \multirow[b]{3}{*}{ Cultivar } & \multicolumn{3}{|c|}{ Ethephon $\left[\mathrm{mg} \cdot \mathrm{L}^{-1}(\mathrm{ppm})\right]$} & \multirow[b]{3}{*}{ Significance } \\
\hline & & 0 & 500 & 1000 & \\
\hline & & \multicolumn{3}{|c|}{ Plant ht $(\mathrm{cm})^{\mathrm{z}}$} & \\
\hline \multirow[t]{2}{*}{ Trailing snapdragon } & Chandelier Yellow & $15.5 \mathrm{~b}$ & $18.2 \mathrm{ab}$ & $19.5 \mathrm{a}$ & $* *$ \\
\hline & Luminaire Yellow & $23.5 \mathrm{a}$ & $25.3 \mathrm{a}$ & $21.7 \mathrm{a}$ & NS \\
\hline Brachyscome & Toucan Tango & $21.5 \mathrm{a}$ & $20.5 \mathrm{a}$ & $20.2 \mathrm{a}$ & NS \\
\hline \multirow{2}{*}{ Calibrachoa } & Million Bells Cherry Pink & $21.5 \mathrm{a}$ & $21.3 \mathrm{a}$ & $17.9 \mathrm{~b}$ & $* * *$ \\
\hline & Trailing Pink & $15.4 \mathrm{a}$ & $15.6 \mathrm{a}$ & $14.8 \mathrm{a}$ & NS \\
\hline \multirow[t]{2}{*}{ Diascia } & Sunchimes Rose & $26.9 \mathrm{a}$ & $23.4 \mathrm{~b}$ & $18.5 \mathrm{c}$ & $* * *$ \\
\hline & Red Ace & $24.3 \mathrm{a}$ & $22.9 \mathrm{ab}$ & $19.6 \mathrm{~b}$ & ** \\
\hline Impatiens & Tioga Red & $25.2 \mathrm{a}$ & $22.1 \mathrm{~b}$ & $20.8 \mathrm{~b}$ & $* * *$ \\
\hline Monopsis & Royal Flush & $43.8 \mathrm{a}$ & $33.1 \mathrm{a}$ & $32.8 \mathrm{a}$ & NS \\
\hline \multirow[t]{3}{*}{ Nemesia } & Aromatica Dark Lavender & $26.0 \mathrm{a}$ & $20.5 \mathrm{~b}$ & $17.8 \mathrm{~b}$ & ** \\
\hline & Blueberry Sachet & $18.8 \mathrm{a}$ & $15.8 \mathrm{~b}$ & $15.1 \mathrm{~b}$ & * \\
\hline & Bluebird & $21.8 \mathrm{a}$ & $19.0 \mathrm{ab}$ & $16.8 \mathrm{~b}$ & * \\
\hline Nolana & Blue Eyes & $52.7 \mathrm{a}$ & $27.2 \mathrm{~b}$ & $27.9 \mathrm{~b}$ & $* * *$ \\
\hline Ivy geranium & King of Balcon & $45.5 \mathrm{a}$ & $34.2 \mathrm{a}$ & $37.1 \mathrm{a}$ & NS \\
\hline Persicaria & Red Dragon & $61.9 \mathrm{a}$ & $55.7 \mathrm{a}$ & $48.8 \mathrm{a}$ & NS \\
\hline \multirow[t]{3}{*}{ Petunia } & Cascadia Pink & $26.7 \mathrm{a}$ & $26.2 \mathrm{a}$ & $23.1 \mathrm{~b}$ & ** \\
\hline & Mini Bright Pink & $23.4 \mathrm{a}$ & $21.5 \mathrm{~b}$ & $20.6 \mathrm{~b}$ & ** \\
\hline & Supertunia Mini Purple & $16.3 \mathrm{a}$ & $17.2 \mathrm{a}$ & $17.9 \mathrm{a}$ & NS \\
\hline Bacopa & Bridal Showers & --- & --- & --- & --- \\
\hline
\end{tabular}

${ }^{\mathrm{z}} 1.0 \mathrm{~cm}=0.39$ inch.

'Mean separation in rows by Duncan's multiple range test.

${ }_{\text {Ns }, *, * *, * * *}$ Nonsignificant or significant at $P=0.05,0.01$, or 0.001 , respectively. 
height when treated with the highest rate of ethephon including calibrachoa 'Million Bells Cherry Pink', diascia 'Red Ace', sweetpotato vine 'Sweet Caroline Bronze', lantana 'Samantha', nemesia 'Bluebird', and petunia 'Cascadia Pink'. Two cultivars, diascia 'Sunchimes Rose' and lantana 'Patriot Cherry', showed a dose response (i.e., decreasing plant height with increasing ethephon concentration). Eight cultivars had the same height reduction with both concentrations of ethephon compared to the control.

Excluding trailing snapdragon 'Luminaire Yellow', which showed an unusual increase in width index, nine of the cultivars had no reduction in width index when treated with ethephon at either concentration compared to the controls (Table 2). Of the cultivars that had reduced width with ethephon treatment, six cultivars were reduced only when treated with the highest rate, four showed a dose response, and seven resulted in the same width index reduction with either concentra- tion compared to the control.

Except for trailing snapdragon ' $\mathrm{Lu}$ minaire Yellow', which showed an atypical increase in flower number, ethephon reduced flower number of eight cultivars when applied at both concentrations, caused a dose response in two cultivars, and reduced flower number in another five cultivars only when the chemical was applied at the highest rate (Table $3)$. The other eleven cultivars had no reduction in flower number, of which five cultivars did not flower regardless of treatment.

Eleven cultivars had both a reduction in plant height and width index. Of these eleven, only three did not experience a delay in flowering including calibrachoa 'Colorburst Red;' sweetpotato vine 'Sweet Caroline Bronze', which does not have significant flowers; and lantana 'Patriot Cherry', which was just starting to flower when plants were harvested.

Ethephon controlled the growth of calibrachoa, nemesia, and petunia cultivars but the response varied among cultivars revealing each cultivar needs testing to find specific rates suited to control growth of each. However, efficacy was obtained for both cultivars of diascia. The two cultivars of impatiens responded similarly to each other with reduced plant height and no effect on width index or delay in flowering. Although ethephon reduced size parameters of lantana 'Patriot Cherry', lantana 'Samantha' was the only cultivar among all those tested that exhibited stress exaggeration (i.e., leaf yellowing and stunted growth). Lantana 'Samantha' plants responded to the ethephon treatments with reduced size parameters, but became unmarketable. This cultivar was slow growing and may have been over-watered during the early part of the experiment aggravating the condition.

Ethephon proved to be an effective tool for improving plant proportion by reducing plant height and/or width index in 22 cultivars of vegetative annuals. Only three cultivars had no reduction in plant height and width

Table 2. The effect of ethephon foliar spray treatment on plant width index $(\mathrm{cm})$ of vegetative annuals.

\begin{tabular}{|c|c|c|c|c|c|}
\hline \multirow[b]{3}{*}{ Common name } & \multirow[b]{3}{*}{ Cultivar } & \multicolumn{3}{|c|}{ Ethephon $\left[\mathrm{mg} \cdot \mathrm{L}^{-1}(\mathrm{ppm})\right]$} & \multirow[b]{3}{*}{ Significance } \\
\hline & & 0 & 500 & 1000 & \\
\hline & & \multicolumn{3}{|c|}{ Plant width $(\mathrm{cm})^{\mathrm{z}}$} & \\
\hline Alternanthera & & $23.8 \mathrm{a}^{\mathrm{y}}$ & $22.1 \mathrm{a}$ & $19.8 \mathrm{a}$ & NS \\
\hline \multirow[t]{2}{*}{ Trailing snapdragon } & Chandelier Yellow & $37.3 \mathrm{a}$ & $38.0 \mathrm{a}$ & $27.9 \mathrm{~b}$ & ** \\
\hline & Luminaire Yellow & $20.6 \mathrm{c}$ & $34.3 \mathrm{a}$ & $27.4 \mathrm{~b}$ & $* * *$ \\
\hline Brachyscome & Toucan Tango & $25.1 \mathrm{a}$ & $24.8 \mathrm{a}$ & $20.2 \mathrm{~b}$ & * \\
\hline \multirow[t]{4}{*}{ Calibrachoa } & Colorburst Red & $53.8 \mathrm{a}$ & $42.3 \mathrm{~b}$ & $40.8 \mathrm{~b}$ & * \\
\hline & Liricashower Rose & $74.0 \mathrm{a}$ & $72.6 \mathrm{a}$ & $68.3 \mathrm{a}$ & NS \\
\hline & Million Bells Cherry Pink & $25.0 \mathrm{a}$ & $24.6 \mathrm{a}$ & $14.5 \mathrm{~b}$ & $* * *$ \\
\hline & Trailing Pink & $59.4 \mathrm{a}$ & $34.5 \mathrm{~b}$ & $27.2 \mathrm{c}$ & $* * *$ \\
\hline \multirow[t]{2}{*}{ Diascia } & Sunchimes Rose & $38.4 \mathrm{a}$ & $27.6 \mathrm{~b}$ & $23.0 \mathrm{~b}$ & $* * *$ \\
\hline & Red Ace & $72.8 \mathrm{a}$ & $47.7 \mathrm{~b}$ & $36.7 \mathrm{c}$ & $* * *$ \\
\hline \multirow[t]{2}{*}{ Impatiens } & Tioga Red & $30.0 \mathrm{a}$ & $30.4 \mathrm{a}$ & $28.3 \mathrm{a}$ & NS \\
\hline & Tioga White & $31.9 \mathrm{a}$ & $29.7 \mathrm{a}$ & $29.2 \mathrm{a}$ & NS \\
\hline Sweetpotato vine & Sweet Caroline Bronze & $16.1 \mathrm{a}$ & $14.3 \mathrm{a}$ & $7.7 \mathrm{~b}$ & ** \\
\hline \multirow[t]{2}{*}{ Lantana } & Patriot Cherry & $21.4 \mathrm{a}$ & $19.0 \mathrm{a}$ & $13.7 \mathrm{~b}$ & $* * *$ \\
\hline & Samantha & $17.7 \mathrm{a}$ & $12.6 \mathrm{a}$ & $11.1 \mathrm{a}$ & NS \\
\hline Monopsis & Royal Flush & $26.9 \mathrm{a}$ & $23.0 \mathrm{a}$ & $22.9 \mathrm{a}$ & NS \\
\hline \multirow[t]{3}{*}{ Nemesia } & Aromatica Dark Lavender & $20.1 \mathrm{a}$ & $14.9 \mathrm{~b}$ & $13.9 \mathrm{~b}$ & $* * *$ \\
\hline & Blueberry Sachet & $23.2 \mathrm{a}$ & $17.9 \mathrm{~b}$ & $15.0 \mathrm{~b}$ & * \\
\hline & Bluebird & $28.3 \mathrm{a}$ & $26.3 \mathrm{a}$ & $24.9 \mathrm{a}$ & NS \\
\hline Nolana & Blue Eyes & $29.5 \mathrm{a}$ & $18.5 \mathrm{~b}$ & $21.7 \mathrm{~b}$ & ** \\
\hline Ivy geranium & King of Balcon & $33.5 \mathrm{a}$ & $25.6 \mathrm{~b}$ & $25.3 \mathrm{~b}$ & $* * *$ \\
\hline Persicaria & Red Dragon & $52.7 \mathrm{a}$ & $50.7 \mathrm{a}$ & $49.5 \mathrm{a}$ & NS \\
\hline \multirow[t]{3}{*}{ Petunia } & Cascadia Pink & $47.1 \mathrm{a}$ & $37.6 \mathrm{~b}$ & $31.3 \mathrm{c}$ & $* * *$ \\
\hline & Mini Bright Pink & $56.7 \mathrm{a}$ & $51.5 \mathrm{a}$ & $45.3 \mathrm{~b}$ & ** \\
\hline & Supertunia Mini Purple & $71.8 \mathrm{a}$ & $63.0 \mathrm{~b}$ & $65.2 \mathrm{~b}$ & * \\
\hline Bacopa & Bridal Showers & $32.5 \mathrm{a}$ & $26.0 \mathrm{~b}$ & $21.5 \mathrm{c}$ & ** \\
\hline Vinca vine & Illumination & $22.1 \mathrm{a}$ & $21.4 \mathrm{a}$ & $18.3 \mathrm{a}$ & NS \\
\hline
\end{tabular}

${ }^{2} 1.0 \mathrm{~cm}=0.39$ inch.

'Mean separation in rows by Duncan's multiple range test.

ss,,$+*+,+* *$ Nonsignificant or significant at $P=0.05,0.01$, or 0.001 , respectively. 
index. Ethephon had irregular results on the two trailing snapdragon cultivars. For most of the other cultivars, visual observations indicated they had more branches, shorter internodes, and denser canopies. Our results are in agreement with Styer (2002) who listed brachyscome, double impatiens, sweetpotato vine, lantana, ivy geranium, trailing petunia, bacopa, and vinca vine as responsive to ethephon although no data was presented. Our results disagree with his on its effectiveness on trailing snapdragon.

\section{Conclusions}

We would recommend that growers include ethephon in their trials of plant growth regulators on vegetative annuals. Different species and cultivars would need individual testing to determine the best rate for each. Ethephon could prove to be a useful tool on trailing and spreading vegetative annuals to facilitate shipping, reduce production costs by allowing closer spacing, and improve quality of plants. Benefits of ethephon application on vegetative annuals may include reduced internode elongation and improved branching on plants that are otherwise hard to control with manual pinching or other plant growth regulators. However, flowering may be delayed. Ethephon may be more effective on some vegetative annuals than antigibberellin-type plant growth regulators. The results of this experiment serve to demonstrate ethephon efficacy on 22 of 27 cultivars of vegetative annuals for future testing. Ethephon caused reductions in plant height and/or width index for 22 cultivars, therefore, it was concluded that ethephon was an effective growth retarding chemical on $81 \%$ of the cultivars tested.

\section{Literature cited}

Aldrich, J.H. and J.G. Norcini. 1996. Effect of plant growth regulators on growth of 'Barbara Karst' bougainvillea. Proc. Fla. State Hort. Soc. 109:3-4.

Grzesik, M. and R.M. Rudnicki. 1989. Effect of growth regulators on growth and the branching of roses "Sonia" and "Mercedes." Acta Hort. 251:411-414.

Nelson, P.V. 2003. Chemical growth regula- tion, p. 433-462. In: Greenhouse operation and management. $6^{\text {th }}$ ed. Prentice Hall, Upper Saddle River, N.J.

Sieminska-Michalak, E. 1989. Influence of growth regulators on branching and elongation of pot plants. Acta Hort. 251: 341-343

Starman, T.W. 1991. Response of Kientzler new guinea impatiens to manual and chemical pinching. HortScience 26(7): 856-857.

Starman, T.W. and J.E. Faust. 1996. Banking on new baskets. Greenhouse Grower $14(3): 86,88,93$.

Starman, T.W. and M.S. Williams. 2000. Growth retardants affect growth and flowering of scaevola. HortScience 35(1): 36-38.

Starman, T.W., K.L. Eixmann, J.M. Minor, and C.L. Wiesinger. 2002. Vegetative annuals vary in response to plant growth regulators. XXVIth Intl. Hort. Congr. Abstr. 1953.

Styer, R.C. 2002. Using florel effectively. Greenhouse Product News 12(10): 10-15.

Styer, R.C. 2003. Don't be shy about florel. Greenhouse Product News 13(3):94.

Table 3. The effect of ethephon foliar spray treatment on flower number of vegetative annuals.

\begin{tabular}{|c|c|c|c|c|c|}
\hline \multirow[b]{3}{*}{ Common name } & \multirow[b]{3}{*}{ Cultivar } & \multicolumn{3}{|c|}{ Ethephon $\left[\mathrm{mg} \cdot \mathrm{L}^{-1}(\mathrm{ppm})\right]$} & \multirow[b]{3}{*}{ Significance } \\
\hline & & $\mathbf{0}$ & 500 & 1000 & \\
\hline & & \multicolumn{3}{|c|}{ Flowers (no.) } & \\
\hline \multirow[t]{2}{*}{ Trailing snapdragon } & Chandelier Yellow & $4 \mathrm{a}$ & $6 a$ & $4 \mathrm{a}$ & NS \\
\hline & Luminaire Yellow & $2 c$ & $11 \mathrm{a}$ & $6 \mathrm{~b}$ & ** \\
\hline Brachyscome & Toucan Tango & $14 \mathrm{a}$ & $10 \mathrm{~b}$ & $6 \mathrm{c}$ & $* * *$ \\
\hline \multirow{2}{*}{ Calibrachoa } & Million Bells Cherry Pink & $3 \mathrm{a}$ & $3 a$ & $0 \mathrm{~b}$ & $* * *$ \\
\hline & Trailing Pink & $47 \mathrm{a}$ & $13 \mathrm{~b}$ & $5 \mathrm{~b}$ & ** \\
\hline \multirow[t]{2}{*}{ Diascia } & Sunchimes Rose & $24 \mathrm{a}$ & $10 \mathrm{~b}$ & $0 \mathrm{c}$ & $* * *$ \\
\hline & Red Ace & $19 \mathrm{a}$ & $1 \mathrm{~b}$ & $0 \mathrm{~b}$ & *** \\
\hline Impatiens & Tioga Red & $16 \mathrm{a}$ & $14 \mathrm{a}$ & $12 \mathrm{a}$ & NS \\
\hline Monopsis & Royal Flush & $0 \mathrm{a}$ & $0 \mathrm{a}$ & $0 \mathrm{a}$ & NS \\
\hline \multirow[t]{3}{*}{ Nemesia } & Aromatica Dark Lavender & $7 \mathrm{a}$ & $1 \mathrm{~b}$ & $0 \mathrm{~b}$ & $* * *$ \\
\hline & Blueberry Sachet & $6 a$ & $4 \mathrm{a}$ & $0 \mathrm{~b}$ & * \\
\hline & Bluebird & $17 \mathrm{a}$ & $3 \mathrm{~b}$ & $0 \mathrm{~b}$ & $* * *$ \\
\hline Nolana & Blue Eyes & $17 \mathrm{a}$ & $5 \mathrm{~b}$ & $1 \mathrm{~b}$ & $* * *$ \\
\hline Ivy gerainum & King of Balcon & $3 a$ & $2 \mathrm{ab}$ & $0 \mathrm{~b}$ & * \\
\hline Persicaria & Red Dragon & $11 \mathrm{a}$ & $9 \mathrm{a}$ & $8 \mathrm{a}$ & NS \\
\hline \multirow[t]{3}{*}{ Petunia } & Cascadia Pink & $13 \mathrm{a}$ & $5 \mathrm{~b}$ & $2 \mathrm{~b}$ & $* * *$ \\
\hline & Mini Bright Pink & $22 \mathrm{a}$ & $12 \mathrm{ab}$ & $4 \mathrm{~b}$ & * \\
\hline & Supertunia Mini Purple & $19 \mathrm{a}$ & $2 \mathrm{~b}$ & $2 \mathrm{~b}$ & ** \\
\hline Bacopa & Bridal Showers & $73 \mathrm{a}$ & $69 \mathrm{a}$ & $52 \mathrm{a}$ & NS \\
\hline Vinca vine & Illumination & $0 \mathrm{a}$ & $0 \mathrm{a}$ & $0 \mathrm{a}$ & NS \\
\hline
\end{tabular}

${ }^{2}$ Mean separation in rows by Duncan's multiple range test.

${ }_{\mathrm{Ns}, *, * *, * * *}$ Nonsignificant or significant at $P=0.05,0.01,0.001$, respectively. 